\title{
Selection and Identification of Cellulase-Producing Bacteria Isolated from the Litter of Mountain and Swampy Forest
}

\author{
WIZNA $^{1 *}$, HAFIL ABBAS $^{2}$, YOSE RIZAL $^{1}$, ABDI DHARMA $^{3}$, AND I PUTU KOMPIANG ${ }^{4}$ \\ ${ }^{1}$ Department of Animal Feed and Nutrition, ${ }^{2}$ Department of Livestock Production, \\ Faculty of Animal Husbandry, ${ }^{3}$ Department of Chemistry, Faculty of Mathematics and Natural Sciences, \\ Universitas Andalas, Kampus Limau Manis, Padang 25163, Indonesia \\ ${ }^{4}$ Research Institute for Animal Production, Departemen Pertanian, Ciawi, Bogor 16002, Indonesia
}

\begin{abstract}
The isolation and selection of cellulase-producing bacteria was conducted to identify the species of cellulolytic Bacillus. The bacteria were isolated from the litter of swampy forest in Pesisir Selatan and mountain forest in Lembah Anai Tanah Datar. These bacteria were cultivated in selective media to obtain bacteria from the genus Bacillus. Six Bacillus isolates were obtained from swampy forest and three Bacillus isolates from mountain forest. These isolates were cultivated in agar medium with carboxymethylcellulose as the carbon source. Colonies which produced clear zones were assumed to be cellulolytic Bacillus. Based on biochemical and morphological examinations the result indicated that these two isolates were Bacillus coagulans and B. amyloliquefaciens. The cellulase activity of B. coagulans and B. amyloliquefaciens were 0.812 and $1200 \mathrm{unit}^{-1} \mathrm{~m}^{-1}$ $C_{1}\left(\beta\right.$-exoglucanase) respectively, 0.368 and 0.488 unit $\mathrm{ml}^{-1}$ to $C_{x}(\beta$-endoglucanase $)$ respectively.
\end{abstract}

Key words: identification, cellulolytic, Bacillus, litter

Agricultural and agro-industrial wastes, which are mostly in the form of lignocelluloses, basically have no economic value may be even be considered of negative value because they still need further treatment. Lignocelluloses consist of hemicelluloses, celluloses, and lignin. Celluloses are the biggest component and can be transformed into energy sources, paper, single-cell protein, glucose, and sorbitol (Putarau 1969; Coral et al. 2002).

One of the goals in biotechnological development is to open the way to utilize microbes in waste bioconversion. Microbe used to treat cellulose-containing wastes could produce extra-cellular enzymes that were able to degrade cellulose material into their smaller components (Bedford and Partridge 2001).

The potency of utilizing cellulase is varied. However, there are some constraints in producing it such as the unavailability of superior microbial strains and a lack of knowledge in enzyme production technology. On the other hand, experts from developed countries acknowledge that countries rich in biodiversity, including Indonesia, are a potential source of microbes for bioprocessing (Fox 1994). Cellulase is usually produced by bacteria and fungi. At present, fungi are usually needed in producing cellulase and for the bioconversion process to improve animal feed quality, but there is a constraint arising from the increase of crude fiber content due to the presence of hyphae which is counted as crude fiber (Coral et al. 2002) .

One of the alternatives is using forest litter decomposer bacteria i.e. Bacillus spp. Bacillus spp. have the biggest number of bacteria, can be found in almost every location, and when chemically tested, they were the most active out of seven genera of bacteria (Jusfah et al. 1995; Yusuf 2000). Litter is organic material residue from dead plants that can be found on the earth's surface or buried in its soil minerals. The speed of the litter decaying process by decomposer

*Corresponding author, Phone: +62-751-71464, E-mail:wiznazhari57@yahoo.com microorganisms (decomposition) depends on the enzymes produced (Spurr and Barnes 1980).

Bacillus spp. has been known to be the producer of various enzymes such as cellulase, hemicellulase, protease, $\alpha$-amylase, urease, xylanase, and chitinase (Cowan 1974; Alexander 1977). These enzymes are expected to be able to transform and change complex molecules, especially lignocellulose which is a limiting factor in animal feed, into simpler molecular components. The objective of this research is to select and obtain a collection of cellulase-producing Bacillus sp. based on their characteristics.

\section{MATERIALS AND METHODS}

Isolation and Selection of Cellulolytic Bacillus. Sampling locations used were several places in the forest litter area of Lembah Anai Tanah Datar and the swampy forest litter in Pesisir Selatan, West Sumatera. One gram of soil sample from each litter was diluted to $10^{-5} \mathrm{cfu} \mathrm{ml}^{-1}$ using fisiologis $\mathrm{NaCl}$ solution. One $\mathrm{ml}$ of this dilution was spread on solid medium of Bacillus that contained $0.25 \%$ bacto agar, $0.6 \%$ peptone, $0.3 \%$ pancreatic digest of casein, $0.3 \%$ yeast extract, $0.3 \%$ beef extract, and $0.001 \% \mathrm{MgSO}_{4} \cdot 7 \mathrm{H}_{2} \mathrm{O}$ for $24 \mathrm{~h}$ at $37^{\circ} \mathrm{C}$ (Cowan 1974). Well-grown colonies were chosen to obtain a pure culture of the bacteria using two loops of an inoculating needle to transfer and inoculate Bacillus sp. onto a petri dish containing NA medium (Cappucino 1987).

The selection of cellulolytic Bacillus sp. was conducted based on the ratio of clear zone to colony diameter after $48 \mathrm{~h}$ on carboxy methyl cellulase (CMC) medium (Sigma) (Cowan 1974). To be able to identify the clear zone more distinctly, a qualitative test was conducted by pouring five $\mathrm{ml}$ of $0.1 \%$ congo red on CMC medium after $24 \mathrm{~h}$ incubation. A clear zone indicated that the isolate was a pure culture of cellulolytic Bacillus sp. After that, each of the grown colonies was recultured again on medium specific for Bacillus and incubated for $24 \mathrm{~h}$ at $37{ }^{\circ} \mathrm{C}$. The colonies were observed 
under microscope. The colonies that looked uniform and grew well indicated that the isolates obtained were pure cultures of cellulolytic Bacillus sp.

Identification of Cellulolytic Bacillus sp. Further identification of these species was conducted by means of macroscopic and microscopic examinations, and biochemical characterization. Macroscopically, the observed characteristics were: color, shape, colony surface, and edge. Microscopically, the tests included: Gram reactions, shape, and cell size. Biochemical tests included: carbohydrate utilization, indole, $\mathrm{H}_{2} \mathrm{~S}$, urease, citrate utilization, catalase activity, motility, and environmental tolerance test by growing the isolate on medium with $\mathrm{pH} 4.0$ and 7.0 in the presence of $\mathrm{NaCl}$ at a final concern of 5.0 and $7.0 \%$. The reactions observed in chemical tests were compared to the identification keys (Buchanan and Gibbons 1974).

Determination of Cellulase Activity of Bacillus sp. Cellulase activity can be measured from the fermentation results by two selected species of Bacillus and are compared with that of Trichoderma harzianum (as the control) in a mixed substrate from sago pulp and rumen content (7:3). Inoculum dosage, fermentation time, fermentation temperature, thickness of substrate, water content, and particle size for the determination of cellulase activity were $2 \%, 48 \mathrm{~h}, 40{ }^{\circ} \mathrm{C}, 2 \mathrm{~cm}, 60 \%$, and $1 \mathrm{~mm}$ respectively.

Isolation of Cellulase Crude Extract. Sampling was conducted an a daily bases to observe the development of cellulase activity. Culture medium was homogenized by adding $75 \mathrm{ml}$ citrate buffer $0.05 \mathrm{M}$ ( $\mathrm{pH} 6$ ) ( $5 \mathrm{x}$ medium weight) for each sample, followed by shaking and filtering. The filtrate was obtained by placsing the homogenate inside a $250 \mathrm{ml}$ Erlenmeyer flask which was placed inside a $500 \mathrm{ml}$ glass beaker filled with ice cubes. During filtration, the homogenate was stirred at low speed and the temperature was kept at $4{ }^{\circ} \mathrm{C}$. The filtrate was centrifuged at $4500 \mathrm{~g}$ for around $15 \mathrm{~min}$ (twice) under refrigeration and then filtered using Whatman no. 1 to obtain crude extract of the enzyme.

Determination of Cellulase Activity. The cellulase activity test was conducted employing the Somogy-Nelson method (Bergmeyer et al. 1981). A volume of $0.5 \mathrm{ml} 1 \%$ (v/w) CMC substrate was pippeted into a reaction tube and was then preincubated for $5 \mathrm{~min}$ in $50^{\circ} \mathrm{C}$ water bath. After adding $0.5 \mathrm{ml}$ enzyme filtrate, the incubation was continued for 45 min (Chaabouni et al. 1994). Enzymatic reactions were stopped by heating the mixture in a boiling water bath for $15 \mathrm{~min}$. Then $1 \mathrm{ml}$ of Somogy-Nelson reagent was added, followed by $15 \mathrm{~min}$ heating. Finally, $1 \mathrm{ml}$ of arsenomolibdic reagent was added into the solution. This mixture was shaken until no more gas was produced, and then diluted with $7 \mathrm{ml}$ distilled water. After the filtrate was separated from its sediment, its absorbance was read at $620 \mathrm{~nm}$ wavelength. Control treatments were the same, except the enzyme was first inactivated. To determine the reducing sugar content from the above enzyme reactions we used a standard curve calibrated with glucose monohydrate. Cellulase activity was defined as the quantity of enzyme that can release $1 \mathrm{mmol}$ glucose $\min ^{-1}$ (Chaabouni et al. 1994).

\section{RESULTS}

Isolation and Selection of Cellulolytic Bacillus. From the isolation and selection results conducted in the laboratory of Research Institute for Animal Diseases (BPPH) Baso Bukittinggi, there were six isolates of Bacillus sp. (GT1, GT2, GT3, GT4, GT5, and GT6) from swampy forest litter and six isolates of Bacillus sp. (LA1, LA2, LA3, LA4, LA5, and

Table 1 Isolation and selection of Baccillus from the litter of swampy forest Pesisir Selatan (GT)

\begin{tabular}{|c|c|c|c|c|c|c|}
\hline \multirow{2}{*}{ Evaluation } & \multicolumn{6}{|c|}{ Isolate } \\
\hline & $\mathrm{GT}_{1}$ & $\mathrm{GT}_{2}$ & $\mathrm{GT}_{3}$ & $\mathrm{GT}_{4}$ & $\mathrm{GT}_{5}$ & $\mathrm{GT}_{6}$ \\
\hline \multicolumn{7}{|l|}{ Staining } \\
\hline Cell shape & Rod & Rod & Rod & Rod & Rod & Rod \\
\hline Spore location & Center & Center & Center & Center & Center & Center \\
\hline Gram test & Positive & Positive & Positive & Positive & Positive & Positive \\
\hline \multicolumn{7}{|l|}{ Morphological observation } \\
\hline Liquid medium & Aerobic & Aerobic & Aerobic & Aerobic & Aerobic & Aerobic \\
\hline \multicolumn{7}{|l|}{ Colony } \\
\hline Shape & Irregular & Irregular & Irregular & Irregular & Irregular & Irregular \\
\hline Elevation & Flat & Flat & Flat & Flat & Flat & Flat \\
\hline Edge & Serrated & Serrated & Serrated & Serrated & Serrated & Serrated \\
\hline Motility & Motile & Motile & Motile & Motile & Motile & Motile \\
\hline \multicolumn{7}{|l|}{ Biochemical test } \\
\hline Catalase & + & + & + & + & + & + \\
\hline Oxidase & + & - & - & - & - & - \\
\hline Glucose fermentation & + & + & + & + & + & + \\
\hline Starch hydrolysis & + & - & - & - & - & - \\
\hline Indole & - & - & - & - & - & - \\
\hline Urease & \pm & - & - & - & - & - \\
\hline Citrate & - & - & - & - & - & - \\
\hline Gas & - & - & - & - & - & - \\
\hline $\mathrm{H}_{2} \mathrm{~S}$ & - & - & - & - & - & - \\
\hline MR (Methyl Red) & - & - & - & - & - & - \\
\hline VP (Voge Prokauer) & + & + & + & - & - & - \\
\hline Nitrate reduction & + & + & + & - & - & - \\
\hline Casein hydrolysis & - & - & - & - & - & - \\
\hline Gelatin hydrolysis & + & - & - & - & - & - \\
\hline TSIA & $\mathrm{r} / \mathrm{r}$ & $\mathrm{r} / \mathrm{y}$ & $\mathrm{r} / \mathrm{y}$ & $\mathrm{r} / \mathrm{y}$ & $\mathrm{y} / \mathrm{y}$ & $\mathrm{y} / \mathrm{y}$ \\
\hline
\end{tabular}

$\mathrm{r}=$ red, $\mathrm{y}=$ yellow. 
Table 2 Isolation and selection of Bacillus from the litter of Lembah Anai forest (LA)

\begin{tabular}{|c|c|c|c|c|c|c|}
\hline \multirow{2}{*}{ Evaluation } & \multicolumn{6}{|c|}{ Isolate } \\
\hline & $\mathrm{LA}_{1}$ & $\mathrm{LA}_{2}$ & $\mathrm{LA}_{3}$ & $\mathrm{LA}_{4}$ & $\mathrm{LA}_{5}$ & $\mathrm{LA}_{6}$ \\
\hline \multicolumn{7}{|l|}{ Staining } \\
\hline Cell shape & Rod & Rod & Rod & Rod & Rod & Rod \\
\hline Spore location & Center & Center & Center & Center & Center & Center \\
\hline Gram test & Positive & Positive & Positive & Positive & Positive & Positive \\
\hline \multicolumn{7}{|l|}{ Morphological observation } \\
\hline Liquid medium & Aerobic & Aerobic & Aerobic & Aerobic & Aerobic & Aerobic \\
\hline \multicolumn{7}{|l|}{ Colony } \\
\hline Shape & Circular & Circular & Circular & Circular & Circular & Circular \\
\hline Elevation & Convex & Convex & Convex & Convex & Convex & Convex \\
\hline Edge & Serrated & Serrated & Serrated & Serrated & Serrated & Serrated \\
\hline Motility & Motile & Motile & Motile & Motile & Motile & Motile \\
\hline \multicolumn{7}{|l|}{ Biochemical test } \\
\hline Catalase & + & + & + & + & + & + \\
\hline Oxidase & + & - & - & - & - & - \\
\hline Glucose fermentation & + & + & + & + & + & + \\
\hline Starch hydrolysis & + & - & + & - & - & + \\
\hline Indole & - & - & - & - & - & - \\
\hline Urease & \pm & - & \pm & - & - & \pm \\
\hline Citrate & - & - & - & - & - & - \\
\hline Gas & - & - & - & - & - & - \\
\hline $\mathrm{H}_{2} \mathrm{~S}$ & - & - & - & - & - & - \\
\hline MR (Methyl Red) & - & - & - & - & + & - \\
\hline VP (Voge Prokauer) & - & + & - & - & + & - \\
\hline Nitrate reduction & - & + & + & - & - & + \\
\hline Casein hydrolysis & + & - & - & - & - & - \\
\hline Gelatin hydrolysis & - & - & - & - & - & - \\
\hline TSIA & $\mathrm{r} / \mathrm{r}$ & $\mathrm{r} / \mathrm{y}$ & $\mathrm{r} / \mathrm{y}$ & $\mathrm{r} / \mathrm{y}$ & $y / y$ & $y / y$ \\
\hline
\end{tabular}

LA6) from Lembah Anai mountain forest litter (Table 1 and 2). From the classification based on "Bergey's Manual of Determinative Bacteriology", there were seven different isolates out of 12 selected isolates, i.e. (GT1), (GT2/LA2), (GT3/LA4), (GT4/GT5 GT6), (LA1), (LA3/LA6), and (LA5).

After that, selection on the ability to degrade was conducted qualitatively by inoculating the above isolates on CMC medium. After $48 \mathrm{~h}$, three out of seven isolates were found to produce clear zones. To examine further about the clear zones and their diameters as depicted in Fig 1 and Table 3. Sufficiently wide clear zones were obtained from Bacillus sp.1 (GT1) and Bacillus sp.2 (LA1) with diameters $37.4 \mathrm{~mm}$ and $12.40 \mathrm{~mm}$ respectively. These two isolates with wide clear zones were then examined to determine their species in the Microbiology laboratory, Department of Biology, Faculty of Mathematics and Natural Sciences, Institut Teknologi Bandung.

Identification of Bacillus sp. Species observation by means of macroscopic and microscopic evaluations as well as biochemical reactions on GT1 and LA1 showed some similarities and some differences. The similarities are: staining tests indicated Gram positive, rod shaped, produced elliptical endospores. From the morphological observation, growth on liquid medium formed a pellicle (aerobic), serrated colony edge, and motile. From biochemical tests, these microbes hydrolyzed starch and casein: sugar fermentation was positive, produced no $\mathrm{H}_{2} \mathrm{~S}$, produced catalase, indicated as alkaline by litmus milk. The differences were: spore location of GT1 in the center of vegetative cell, irregular colony shape with flat elevation, positive hydrolysis of gelatin, and nitrate reduction. Whereas, spore location of LA1 were in the center to the end of vegetative cell, circular colony shapes with

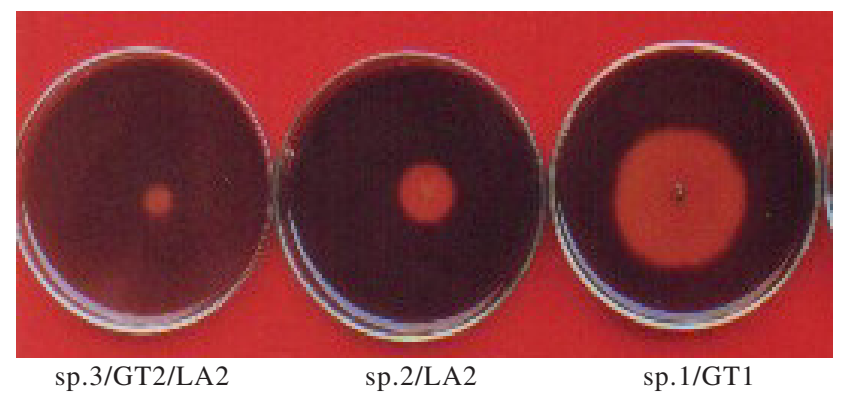

Fig 1 Clear zones of Bacillus sp. on CMC medium.

Table 3 Clear zone diameters of isolates obtained from isolation and selection on CMC medium (48-hour inoculation)

\begin{tabular}{lcc}
\hline Isolate & Species & Clear zone diameter $(\mathrm{mm})$ \\
\hline (GT1) & $\mathrm{sp} .1$ & 37.40 \\
(LA1) & $\mathrm{sp} .2$ & 12.40 \\
(GT2/LA2) & $\mathrm{sp} .3$ & 09.32 \\
(GT3/LA4) & $\mathrm{sp} .4$ & - \\
(GT4/GT5GT6) & $\mathrm{sp} .5$ & - \\
(LA3/LA6) & $\mathrm{sp} .6$ & - \\
(LA5) & $\mathrm{sp} .7$ & - \\
\hline
\end{tabular}

convex elevation, negative hydrolysis of gelatin, and negative nitrate reduction. The caracteristic of GT1 and LA1 as well as the defferences of B. amyloliquefaciens and $B$. coagulans at Table 4.

Cellulase Activity. Average values of cellulase activities of Bacillus and T. harzianum in mixed substrate containing sago pulp and rumen content were as follows. Cellulase activity of $\mathrm{C}_{\mathrm{x}}$ and $\mathrm{C}_{1}$ of $B$. amyloliquefaciens were 0.368 and 0.812 unit $\mathrm{ml}^{-1}$ respectively, $B$. coagulans were 0.488

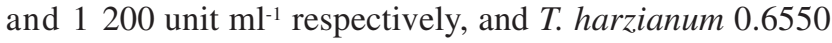
and 0.3070 unit $\mathrm{ml}^{-1}$ respectively (Table 5). 
Table 4 Characteristics of Bacillus sp.1 (GT1), Bacillus sp.2 (LA1), B. amyloliquefaciens and B. coagulans

\begin{tabular}{|c|c|c|c|c|}
\hline \multirow{2}{*}{ Evaluation } & \multicolumn{4}{|c|}{ Isolate } \\
\hline & Bacillus sp.1 (GT1) & Bacillus sp.2 (LA1) & Bacillus amyloliquefaciens & Bacillus coagulans \\
\hline \multicolumn{5}{|l|}{ Staining } \\
\hline Cell shape & Rod & Rod & Rod & Rod \\
\hline Spore location & Center & Center-end & Center & Center-end \\
\hline Gram test & Positive & Positive & Positive & Positive \\
\hline \multicolumn{5}{|l|}{ Morphological observation } \\
\hline Liquid medium & Aerobic & Aerobic & Aerobic & Aerobic \\
\hline \multicolumn{5}{|l|}{ Colony } \\
\hline Shape & Irregular & Circular & Irregular & Circular \\
\hline Elevation & Flat & Convex & Flat & Convex \\
\hline Edge & Serrated & Serrated & Serrated & Serrated \\
\hline Motility & Motile & Motile & Motile & Motile \\
\hline \multicolumn{5}{|l|}{ Biochemical test } \\
\hline Catalase & + & + & + & + \\
\hline Glucose fermentation & + & + & + & + \\
\hline Lactose fermentation & - & - & & \\
\hline Sucrose fermantation & + & + & & \\
\hline Starch hydrolysis & + & + & + & + \\
\hline Indole & - & - & & - \\
\hline Urease & - & - & & \\
\hline Citrate & - & - & & \\
\hline Triple sugar-iron & + & + & & \\
\hline $\mathrm{H}_{2} \mathrm{~S}$ & - & - & - & - \\
\hline Methyl red & + & + & & \\
\hline Voges-Proskauer & - & - & & \\
\hline Nitrate reduction & + & - & + & - \\
\hline Casein hydrolysis & + & + & + & + \\
\hline Gelatin hydrolysis & + & - & + & \\
\hline Litmus milk & alkaline & alkaline & alkaline & \\
\hline
\end{tabular}

Table 5 Average value of cellulase activities of Bacillus amyloliquefaciens, B. coagulans and Trichoderma harzianum

\begin{tabular}{lcc}
\hline Isolates & \multicolumn{2}{c}{ Average value of cellulase activity (unit $/ \mathrm{ml})^{*}$} \\
\cline { 2 - 3 } & $\mathrm{C}_{\mathrm{x}}(\beta$-endoglucanase $)$ & $\mathrm{C}_{1}(\beta$-exoglucanase $)$ \\
\hline B. amyloliquefaciens & $0.4880 \pm 0.046$ & $1.2000 \pm 0.150$ \\
B. coagulans & $0.3680 \pm 0.043$ & $0.8120 \pm 0.145$ \\
T. harzianum & $0.6550 \pm 0.045$ & $0.3070 \pm 0.013$ \\
\hline
\end{tabular}

*Cellulase activity is based on cellulase crude extract.

\section{DISCUSSION}

The results of this research are in line with the characteristics determined by Buchanan and Gibbons (1974) and Holt et al. (1994) based on qualifications from "Bergey's Manual of Determinative Bacteriology", that a Bacillus is classified into the kingdom of Prokaryotes, division Bacteria, class Schyzomycetes, order Eubacteriales, family Bacillaceae, and genera Bacillus. The characteristic of Bacillus sp. cultivated on NA medium was that the clear zone of Bacillus sp.1 (GT1) was wider than that of Penicillium on CMC medium as reported by Dharma (1998) (37.4 $\mathrm{mm}$ vs $15.60 \mathrm{~mm}$ ).

Identification results of these two species were in line with Buchanan and Gibbons (1974) and Holt et al. (1994), that $B$. amyloliquefaciens was Gram positive, rod shaped, produced elliptical endospores, and located in the center of vegetative cell, growth on liquid medium formed pellicle (aerobic), irregular colony shape with flat elevation, motile, positive hydrolysis of gelatin and nitrate reduction, and $B$. coagulans was Gram positive, rod shaped, produced elliptical endospores, and located in the center to the end of vegetative cell, growth on liquid medium formed pellicle(aerobic), circular colony shapes with convex elevation, motile, negative hydrolysis of gelatin, and negative nitrate reduction. From the results of biochemical reactions, GT1 is B. amyloliquefaciens and LA1 is B. coagulans.

The value of the cellulase activity of both Bacillus species were lower compared to those of enzymes produced by Bacillus subtilis strain-CBTK 106 cultivated for $72 \mathrm{~h}$ on banana peel medium completed with $\mathrm{C}$ and $\mathrm{N}$ sources and several minerals, such as carboxy methyl cellulase (CM Case) 9.6 IU gds ${ }^{-1}$ (gram dry matter substrate). Filter paperase (FPase) $2.8 \mathrm{IU} \mathrm{gds}^{-1}$ and cellobiase $4.5 \mathrm{IU} \mathrm{gds}^{-1}$ (Chundakkadu 1999). Likewise, the cellulase activity in the fermentation of oil palm empty fruit bunch using Penicillium sp. was higher

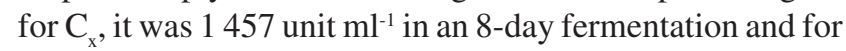

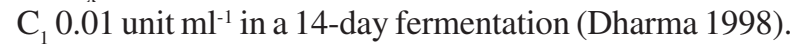

\section{REFERENCES}

Alexander M. 1997. Introduction to Soil Microbiology. $2^{\text {nd }}$ Ed. New York: John Wiley.

Bedford MR, Partridge GG. 2001. Enzyme in Farm Animal Nutrition. Marlborough Wiltshire: Finnfeeds Cab Publ.

Bergmeyer HU, Bergmeyer J, Grab M. 1981. Methods of Enzymatic Analysis 2. Amsterdam: Verlag Chemie.

Buchanan RE, Gibbons NE. 1974. Bergey's Manual of Determinative Bacteriologi. 9th Ed. California: The Williem and Wilkins Company.

Cappucino JG, Sherman N. 1987. Microbiology a Laboratory Manual. $2^{\text {th }}$ Ed. California: The Benjamins Columning Publ Company.

Chaabouni SM,Taieb NH, Mosrati R, Radhouane E.1994. Preliminary assestment of Pennicillium occitanis cellulase. J Enzyme Microbiol 16:538-542.

Chundakkadu K. 1999. Production of bacterial cellulases by solid state bioprocessing banana wastes. J Biores Technol 69:231-239. 
Coral G, Arikan B, Unaldi MN, Guvenmes H. 2002. Some properties of crude carboxymethyl cellulase of Aspergillus niger Z10 wildtype Strain. Turki J Biology 26:209-213.

Cowan ST. 1974. Cowan and Steel's Manual for the Identification of Medical Bacteria. $2^{\text {nd }}$ ed. Ames: Cambridge University Pr.

Dharma B. 1998. Production of cellulases by Penicilium sp. on different substrate solid state plant at different time [Thesis]. Padang: Universitasn Andalas.

Fox JK. 1994. Biodiversity promises great prospecting. J Biotechnol 13:544-545.

Holt JG, Krieg NR, Sneath PHA, Staley JT, Williams ST. 1994. Bergeys Manual of Determinative Bacteriology. $9^{\text {th }}$ Ed. Baltimore: The Williams and Wilkins Company. MO. USA.
Jusfah J, Rangkuti D, Muchtar E. 1995. Inventory Microorganism as Litter Decomposer in Lembah Anai. In: Annual Report of Project Japan International Cooperation Agency (JICA). Universitas Andalas. 7:105-109.

Putarau JM. 1969. By-product of cane sugar industry. In: an Introduction to their Industrial Utilization. $1^{\text {st }} \mathrm{Ed}$. New York: Elsevier Publ, Company.

Spurr SH, Barnes BV. 1980. Forest Ecology. $3^{\text {rd }}$ Ed. New York: John Willey and Sons.

Yusuf S. 2000. Litter decomposer bacteria found in swampy forest. An observation considering the factors of open and closed area [Thesis]. Padang: Andalas University. 